\title{
The necessary indeterminacy of self- determination: Politics, law and conflict in the Horn of Africa
}

\author{
Alex de Waal $^{1,2}$ | Sarah M.H. Nouwen ${ }^{2}$
}

${ }^{1}$ World Peace Foundation, Somerville, Massachusetts

${ }^{2}$ London School of Economics, Firoz Lalji Centre for Africa, London, UK

\section{Correspondence}

Alex de Waal, World Peace Foundation, 169 Holland St, Somerville, MA 02144, USA. Email: alex.dewaal@tufts.edu

Funding information

Centre for Public Authority and International Development, Firoz Lalji Centre for Africa, London School of Economics, Grant/Award Number: ES/P008038/1; Isaac Newton Trust, Grant/Award Number: RG79578; Leverhulme Trust, Grant/Award Number: PLP-2014-067; World Peace Foundation, Economic and Social Research Council, Grant/Award Number: ES/L010976/1

\begin{abstract}
This article frames a themed collection on Nationalism and Self-determination in the Horn of Africa. It demonstrates how the praxis of self-determination in the Horn of Africa has contributed to normative developments. On the basis of case studies of Eritrea, Ethiopia, Somalia and Sudan/ South Sudan this article argues that nationalism and selfdetermination have had different meanings in the political cultures across the different countries and have changed over time. We contend that such indeterminacy is unavoidable and should be welcomed. Nationalism is driven by historical circumstances that are contingent and often transitory. Self-determination claims based on such nationalism are equally contingent and transitory. When the principle of self-determination gets translated into concrete legal entitlements (for instance, a referendum on independence), it tends to solve one problem only by creating others. Instead, the pursuit and realization of self-determination require constant political processes.

\section{KEYWORDS}

Africa, Ethnic Nationalism, International Law, Nationhood / National Identity, Partition, Self-determination
\end{abstract}




\section{1 | THE NECESSARY INDETERMINACY OF SELF-DETERMINATION: POLITICS, LAW AND CONFLICT IN THE HORN OF AFRICA}

The Horn of Africa has been a laboratory for international political orderings since the 19th century, testing the bounds of possible territorial and sovereign dispensations. In the current era, the Horn has continued to be a crucible of innovation. Along with the former USSR and former Yugoslavia, the Horn of Africa stands out as a rare region in which boundaries have been redrawn in the last generation-a process which is likely not to have reached its end. What makes the Horn particularly fascinating is that substantively variant concepts of 'self-determination' have informed the politics of each of the countries of the Horn, and each one of these varying understandings has intersected with the contingencies of political events to generate outcomes that are far from predetermined.

Focusing on the varieties of self-determination-in aspiration, theory, law and execution-this special collection aims to write a nuanced and comparative account of self-determination in the Horn of Africa. It revisits the issues raised in the seminal volume edited by loan Lewis, Nationalism and Self-Determination in the Horn of Africa (Lewis, 1983), illuminating the interplay between law, political narratives and political contingencies-including some intriguingly arcane articulations of political theory. It shows how the same term has different meanings to different people and can play out in very different ways in different contexts and different times. Challenging the literature that considers self-determination's indeterminacy its fundamental weakness, the Horn of Africa suggests that such indeterminacy is unavoidable and should be welcomed.

This collection highlights the challenges in giving effect to the principle of self-determination, including its subjugation to power politics. But it also shows how the concept of self-determination does important work in support of the emancipation of oppressed peoples: it provides a means to articulate the right to collective political agency. In this regard, it is quite distinct and more emancipatory than other recent innovations in international norm setting, such as the responsibility to protect (R2P), which depoliticize the specific situation and weaken the political agency of the suffering population.

\section{2 | SCOPING THE ISSUES: THE HORN OF AFRICA, SELF-DETERMINATION AND NATIONALISM}

For the purposes of this article, we define the Horn as six internationally recognized states (Djibouti, Eritrea, Ethiopia, Somalia, South Sudan and Sudan), two of which have only recently obtained such recognition (Eritrea in 1993 and South Sudan in 2011). The Republic of Somaliland declared itself independent in 1991, but has not received international recognition.

Self-determination is harder to define. The world's major human rights conventions refer to self-determination as the right of 'all peoples' 'freely [to] determine their political status and freely [to] pursue their economic, social and cultural development'.1 For the purposes of this special collection, we identify as the core idea of self-determination the notion that a collectivity of people possesses the right to govern itself. Rather than providing singular answers to the questions as to how to define a people and what the right entails concretely, the aim of the special collection is to consider the different conceptualizations of the principle in the various specific political contexts in which it has been invoked and is playing out.

Given the predominant understanding of self-determination as national self-determination-the 'people' invoking self-determination primarily considering themselves a 'nation'-the third key issue to consider is that of nationalism including the related questions of national identity and nation-building. There is a vast literature on this, but for our purposes, we distil it to the point that nationalism can be understood as efforts to promote the principle of congruence between political governance and 'nations' (Gellner, 1983). This is itself hugely complex. We now understand how nations have been imagined and constructed in the modern era, with mythical ancestries projected back into the past (Anderson, 1999). A back-handed tribute to the power of the territorial-national imaginary is that the 
African peoples of the 'Black Atlantic' have, despite a century of Pan-Africanist sentiments and projects, been unable to formulate a viable alternative (Gilroy, 1993).

Martti Koskenniemi has explored national self-determination's dual relationship to statehood-in its patriotic sense, justifying it and, in its secessionist sense, challenging it-which stems from two diverging understandings of the origins of 'nations' (Koskenniemi, 1994). In the 'Hobbesean' understanding, the ruler first forges a state from anarchy and then uses nationalism as an instrument for the consolidation of the state by means of creating a unified sense of nation among the citizens of that state.

However, in the 'Rousseauesque' understanding of the nation, it is believed that a primordial form of national identity precedes the formation of a modernizing nation-state and can be identified in a distinct, ahistorical manner. This romantic notion of the nation chimes with 'everyday primordialism': the popular belief that identities are fixed and that different identities can be expected to come into conflict (Fearon \& Laitin, 2000). While social scientists are almost unanimous that identities are socially and politically constructed, the label 'identity conflict' seems to lead inexorably towards the consolidation of those political constructions, through the organization of the conflict and the organization of the peace.

Marxist-Leninist theory on nationalism and self-determination combines the Hobbesean and Rousseauesque understandings. In his 1913 tract, Stalin defined a nation in the following manner (Stalin, 1913):

A nation is a historically constituted, stable community of people, formed on the basis of a common language, territory, economic life, and psychological make-up manifested in a common culture. It goes without saying that a nation, like every historical phenomenon, is subject to the law of change, has its history, its beginning and end.

This is no mere historical curiosity. It led to the Soviet Union's constitutional formula for the cohabitation of 'nations' within a federal state and to a practice of administering national units in a distinctive manner that reinforced that national identity (Brubaker, 1994). The current Ethiopian federal constitution derives from this same communist theory of nationalism and self-determination.

The sibling issues of nationalism and self-determination play particularly interesting roles in the modern history of the Horn of Africa. The histories of each of the current states of the region, and how each came to take its current shape, are ipso facto discussions of national self-determination-albeit with very different scripts. Insofar as processes of secession and boundary-making are incomplete, narratives, concepts and norms relating to national selfdetermination remain relevant. This collection shows how governments, political movements and public intellectuals in the Horn of Africa have made use of the political idea, theory and law of self-determination. Their usage also illustrates and illuminates these theories and norms, showing their inconsistency, contingency, malleability and subordination to political circumstance.

\section{3 | LEGAL INDETERMINACY}

The fact that self-determination has had multiple meanings and applications in the Horn of Africa is not incompatible with the international law on self-determination. For in international law, too, self-determination has multiple meanings, depending on the context.

\section{1 | Colonial context}

Self-determination has the clearest legal ramifications in the context of decolonization. It was in this context that self-determination developed from a political idea into an international legal right, albeit only when the process of decolonization was already well under way. 
A key moment for the development of this legal right was in 1960, when the United Nations General Assembly adopted the 'Declaration on the Granting of Independence to Colonial Countries and Peoples'. The adoption was a triumph for African and Asian anti-colonial leaders. Paragraph 2 declared that 'All peoples have the right to selfdetermination; by virtue of that right they freely determine their political status and freely pursue their economic, social and cultural development.' Subsequent paragraphs made the right more concrete, ruling out delays in granting independence and asserting that the disruption of territorial integrity of countries was contrary to the UN Charter. Paragraph 5 is the most significant:

Immediate steps shall be taken, in Trust and Non-Self-Governing Territories or all other territories which have not yet attained independence, to transfer all powers to the peoples of those territories, without any conditions or reservations. (United Nations, 1960)

Paragraph 5 shows that initially, the legal ramification of self-determination was not so much the right of a people, as an obligation on the colonizer, namely, to prepare the colony for independence. However, in situations where specific colonizing powers refused to do so, the emphasis shifted towards the right of the colonized people freely to express their wishes as to their future political status, including the option of independence. 2 In practice, the substantive part of the right has often been considered more important than the procedural: situations in which former colonies became independent were considered compatible with the right to self-determination, even where the relevant people had not been consulted. With or without any consultation procedure, in the context of decolonization, self-determination is a one-off event that can be 'achieved'.

The General Assembly resolutions that developed the right to self-determination in the colonial context conceived of the people entitled to that right as 'nations' in Koskenniemi's Hobbesean sense: the nation consists of the people of an already existing territorial-administrative unit, namely, that of the colony. Despite their scorn for the arbitrariness of colonial boundaries, national liberation movements (with the notable exception of the Somalis) did not prioritize a Rousseauesque understanding of a 'people', defined by ethnic, linguistic and other cultural features. They primarily invoked self-determination as a right to shed off the colonial yoke, while also accepting that the people entitled to exercise this right were themselves yoked together on the basis of colonial boundaries. Contrary to Judge Dillard's famous statement that '[i]t is for the people to determine the destiny of the territory and not the territory the destiny of the people' (separate opinion Judge Dillard, Western Sahara Advisory Opinion, 1975, p. 122) 'the people' entitled to the right to self-determination in the colonial context are thus in fact defined by the territory: the people is the collective of inhabitants of the colony.

Self-determination in this sense could develop in international law because it could be squared with other fundamental rules in international law, in particular the principle of 'territorial integrity'. Decolonization could be reconciled with the principle of territorial integrity because the colony was declared to have a separate territorial status from the colonial state (United Nations, 1970).

Indeed, the principle of territorial integrity held value for colonies (United Nations, 1960). It meant that the colonizer was not allowed to slice off part of the territory and grant independence only to the remainder. The International Court of Justice (ICJ) confirmed this when it found in its Advisory Opinion of 2019 that the United Kingdom's separation of the Chagos Archipelago (including the island Diego Garcia, currently leased to the US for a naval basis) from Mauritius just before Mauritius's independence had been in violation of international law and that the UK is therefore 'under an obligation to bring to an end its administration of the Chagos Archipelago as rapidly as possible.' (ICJ, 2019, para. 183).

In addition to self-determination and territorial integrity, a third legal concept became prominent in the context of decolonization: uti possidetis ('as you possessed'). The principle developed in Spanish America primarily to provide the newly independent states, previously all belonging to Spain, with a title to their territory. The traditional modes of acquiring title to territory (occupation, prescription and cession) were particularly deficient with respect to sparsely populated areas. The newly independent states wanted to avoid external claims to such territory on the 
basis of the argument that the territory was terra nullius and therefore free for occupation. Uti possidetis provided a title to territory based on law, rather than facts on the ground.

Uti possidetis also addressed an issue that arose because all the states emerged from the same colonial power: where were the boundaries among the newly independent states? According to uti possidetis, the previously internal administrative limits applied by the colonizer would become the new international boundaries. In the words of the International Court of Justice: 'uti possidetis juris is essentially a retrospective principle, investing as international boundaries administrative limits intended originally for quite other purposes.' (ICJ, 1992, para. 43).

Africa faced somewhat different issues upon decolonization: there was less of a risk of arguments about terra nullius, and most of the boundaries of the newly independent states followed inter-colonial boundaries determined by the different colonial powers, rather than a previously intra-colonial administrative boundary (ICJ, 2013, separate opinion Judge Yusuf, paras 13 and 14). The emphasis of the Organization of African Unity (OAU) was therefore elsewhere: it wanted to avoid border wars among the new states and ban support for secessionist and irredentist movements. Its founding charter thus listed as third among the principles to which its member pledged adherence: 'respect for the sovereignty and territorial integrity of each State and for its inalienable right to independent existence' (OAU Charter, 1963, Article III, para 3). A year later, the organization's Assembly of Heads of State and Government, meeting in Cairo, 'solemnly declare[d] that all Member States pledge themselves to respect the borders existing on their achievement of national independence.' (Organization of African Unity, 1964). While it shares the aspect of respect for boundaries, this principle differs from uti possidetis in important ways. First, in terms of its scope, it is not limited to situations in which internal administrative boundaries have become international boundaries; this principle also applies to boundaries between states emerging from different colonial powers. Second, the boundary that has to be respected is not the pre-colonial or even the colonial boundary, but the boundary existing on the relevant states' achievement of independence, for instance that of Ethiopia including Eritrea or that of Somalia as encompassing both British and Italian Somaliland (see ICJ, 2013, separate opinion Yusuf, paras 23-24). Thus, whereas the Spanish American uti possidetis principle referred to colonial law to determine boundaries, the OAU principle merely wished to avoid military disputes about borders; it did not in and of itself determine how such disputes would be resolved. This difference between the Spanish American uti possidetis principle and the OAU principle was underlined by Abdulqawi Yusuf, a (Somali) judge on the International Court of Justice, in a separate opinion:

The rejection by the OAU/AU of a rearrangement of borders on ethnic lines or on the basis of historical and geographic claims does not amount to an acceptance of colonial law as title to territory. It was certainly not the intent of the member States of the OAU or the AU to collectively ratify, through the adoption of this principle, the General Act of Berlin of 1885 or to recognize the administrative law of the colonial powers. (ICJ, 2013, para. 33)

The title of the famous Cairo declaration, namely, a resolution on 'border disputes among African states' (emphasis added), already indicates that it does not prohibit states to agree on boundary adjustments or to grant peoples within their states the right to secession.

Whether we speak of respect for boundaries existing on the achievement of independence, the principle of uti possidetis or the principle of territorial integrity, none of these principles is legally in tension with the right to selfdetermination. On the contrary, all of these protect one element of the right to self-determination as interpreted beyond the colonial context, namely, the right of a people to be free from foreign interference.

Given the preeminence of the Hobbesean understanding of a 'people' in the colonial context, the crucial question for the purposes of identifying who is entitled to self-determination is not 'what is a people', but 'what is a colony' (Healy, 1983, p. 15). The UN General Assembly determined that 'territories ... known to be of the colonial type' 'prima facie' exist in case of 'a territory which is geographically separate and is distinct ethnically and/or culturally from the country administering it' (United Nations, 1960, Annex, Principle IV). De facto interpreting the criterion of geographic separation as separation by an ocean, the General Assembly in effect recognized as colonies only 
territories subject to so-called 'blue-water' or 'salt-water' colonialism. It did not recognize a right to selfdetermination of peoples within territorially contiguous multiethnic states, whether those be indigenous imperial states that were never colonized (such as Ethiopia), decolonized multiethnic states with a dominant ethnic group or groups (such as Nigeria, Indonesia or Pakistan) or imperial states that were then colonized (such as Burma or Sudan). In the cases of East Timor, Southern Rhodesia and Western Sahara, the General Assembly continued to recognize the people's right to self-determination despite the departure of the colonial administrator on the ground that the respective people had not been able to exercise its right to self-determination (United Nations, 1976, 1977, 1979). However, entities that were denied a form of self-government that had once been promised, even if by the General Assembly as in the case of Eritrea (United Nations, 1950), never obtained such recognition.

In sum, even in the colonial context, self-determination has an element of indeterminacy in that the law on selfdetermination is not self-executing. That is, the legal consequences of the right are not triggered by the law itself but require a political decision, in this context by the UN General Assembly to recognize a particular group as being entitled to the right to self-determination. So while self-determination may have developed from a political principle into a legal norm and the legal consequences of the application of that norm have crystallized considerably, 'the question of the ambit of self-determination, the territories to which it applies, has arguably remained as much a matter of politics as law', carrying with it all politics' indeterminacies (Crawford, 2008, p. 115).

\subsection{Outside the colonial context}

The exact entitlements that the right to self-determination generates outside the colonial context have depended on the definition of the rights holder: the 'people' or the 'nation'.

First, according to international law, the right to self-determination inheres in a people constituting a nation in the Hobbesean sense, namely, the people as formed by already constituted states (for instance, the people of Ethiopia), including the people of states that have become independent pursuant to the right to self-determination in the context of decolonization (for example, the people of Nigeria or Sudan). In this context, the right to selfdetermination entitles a people to territorial integrity and non-interference in internal affairs; the corollary of which is an obligation on other states not to intervene in their internal affairs. Some have argued that the right to selfdetermination of the people of an already existing state also has a more positive dimension: the right to choose their own system of government, with a view to determining their economic, social and cultural development (Higgins, 1994, p. 120). This dimension is frequently considered part of the right to 'internal self-determination': 'a people's pursuit of its political, economic, social and cultural development within the framework of an existing state.' (Supreme Court of Canada, 1998, para 126) In contrast to the right to self-determination in the colonial context, in this non-colonial context, both the negative (a right to non-interference) and the positive (a right to choose the form of government) are continuous rights.

More controversial has been whether, as a matter of international law, groups within states (for instance, the 'southern Sudanese' in Sudan or the Bari in South Sudan) also count as 'peoples' entitled to (some form of) selfdetermination and, if so, what this entitles them to. As soon as territorial boundaries no longer define people, it is difficult for international law in abstracto to define a people and to reconcile that people's right to self-determination with another people's competing right to self-determination, for instance, that of the people of the state as a whole. It has been argued that groups within states are, like the population of a state as a whole, entitled to the right to 'internal self-determination', but there is little settled law as to what this right entails. The most specific part of the common definition of the right to internal self-determination ('within the framework of an existing state') provides what it does not entitle a group to: independence through unilateral secession (that is, secession without the consent from the state from which the territory is seceding). Only in this way can an international legal entitlement to selfdetermination for nations other than in the Hobbesean understanding be reconciled with international law's norm of territorial integrity. 
Two caveats are in place though. First, the absence of an entitlement is not the same as a prohibition: international law generally does not speak to secessionist movements (ICJ, 2010). If a secessionist movement is successful, international law can accept the outcome. But it does speak to states and prohibits them from undermining the territorial integrity of another state, for instance by supporting secessionist movements. Second, international law does not prohibit states from granting self-determination rights, including the possibility of secession, as a matter of domestic law. Constitutions that do so, as in the USSR and Ethiopia, thus contain a broader reading of selfdetermination than that in the international law, but are still compatible with international law.

Some scholars have argued that a group within a state has the right to secede unilaterally as a matter of international law if the state commits massive, discriminatory human rights violations against the group's members, or if 'internal self-determination', through self-government or participation in the national government, is denied (Hannum, 1998, p. 16). This theory of 'remedial secession' grants the right to external self-determination, that is, self-determination as a right to independence, in the situation that the right to internal self-determination is denied. The theory has obtained some support in (quasi-) judicial opinions, but always in obiter statements: in no case has the theory of remedial secession been decisive. More importantly, there has been hardly any state practice, crucial for the development of customary international law, in which the theory was successfully invoked. Moreover, in some instances of group-based political repression, for instance, Darfur in Sudan, the repressed groups have not framed their cause as a demand for self-determination, or the resistance is fragmented in such a way that any claim to self-determination is not taken seriously.

In sum, the international law on self-determination is indeterminate in that it means different things in different circumstances and that its most radical entitlement, the entitlement to become an independent state, depends, even in the colonial context, on political recognition. But rather than this being a weakness of the law, it is its strength, for it acknowledges that recognition of 'nations' cannot be a matter for international law because, as Koskenniemi writes, '[t]here are no general criteria by which nations can be recognized.' (Koskenniemi, 1994, p. 261). The theory of remedial secession, too, lacks sufficient criteria for bestowing upon oppressed nations a right to independence. As Koskenniemi asks rhetorically

If the call for national self-determination does not emerge from any given, authentic 'nationhood', but is only a way to enlist popular support for the struggle against political oppression, there seems to be no way of identifying the 'nations' that possess this right without the identification of oppression, that is to say, the existence (or absence) of a legitimate cause of political struggle. How, one may ask, can international lawyers be expected to do this? (Koskenniemi, 1994, p. 262)

\section{I HOW THE HORN OF AFRICA SHAPED THE PRAXIS AND LAW OF SELF- DETERMINATION}

The Horn has played an important role in the practices that shaped the international norms pertaining to self-determination, in three respects in particular. The first and most important is the leading role of Ethiopian Emperor Haile Selassie I in the fashioning of the post-colonial territorial dispensation in Africa and in particular in the adoption of the principle of respect for borders existing at the time of achieving independence and the salt-water thesis for the identification of a 'colony'. This entailed the delegitimization of Somali and Eritrean anti-colonial nationalism. Somalia's independence movement was framed around an irredentist goal to unite all the Somali speaking people of the Horn and the territories they inhabited in a single state, a goal that directly challenged the principle of territorial integrity and was pursued unsuccessfully for three decades. This was decisively defeated by Ethiopian diplomacy in the 1960s, underwritten by Ethiopian force of arms in the 1970s. Eritrean nationalism appeared to have suffered the same fate until the military tide was reversed, leading to Eritrea's independence de facto in 1991 and de jure in 1993. Second, the Horn-specifically Eritrea-was the place of the first redrawing of boundaries that took place in the 
1990s, demonstrating that secession can be compatible with respect for the principle of territorial integrity, uti possidetis and adherence to boundaries received upon independence, as long as the rump state agrees. Third, the Horn has been a site for the development of the norm of the Responsibility to Protect, a norm that interacts with self-determination in complex ways: while it can be seen as shoring up the theory of remedial secession, R2P is fundamentally at odds with self-determination as a right to political self-governance.

\section{1 | Respect for boundaries upon independence, uti possidetis and the salt-water thesis}

With remarkably few alterations, most state boundaries in contemporary Africa correspond to those arbitrarily drawn by colonial powers. Most of the European conquistadors at the Berlin conference table in 1885 had never set foot on the continent, and they drew lines on the map without the slightest reference to the identities, livelihoods or wishes of the populations across whose lands their lines ran. Some ethnic groups were cut in two (or more), and peoples who had no history of common government, in some cases even any significant prior interaction, were assembled together as subjects of the same foreign administration. The arbitrary character of the territories defined by these borders animated Pan Africanists, notably the Ghanaian leader Kwame Nkrumah, who aspired to create a United States of Africa and proclaimed that no African could be truly free until all were free. This was a form of romantic continental Pan-African self-determination and, in some versions, embracing the African diaspora of the Americas as well. In his practical politics, however, Nkrumah enjoined Pan-Africanists to 'seek ye first the political kingdom' (Biney, 2011, p. 3), which was a call for taking control of the existing colonial governmental machinery within the existing colonial territories, more in line with a Hobbesean understanding of the nation.

In the Horn, however, the boundaries were not wholly arbitrary, corresponding to a significant degree to the long-established spheres of control of the kingdoms of the Nile, the kingdoms of the Ethiopian highlands, and the city-states of the Indian Ocean littoral. As Christopher Clapham points out, it is precisely because these boundaries possess some historic cogency that they are so hotly disputed (Clapham, 2016). Where an indigenous stateformation process of nation-building had occurred, albeit to a limited degree, Pan-Africanism was subordinate to local nationalism.

Three years after their success in the General Assembly's adoption of the 'Declaration on the Granting of Independence to Colonial Countries and Peoples', African leaders convened in Addis and established the OAU with the primary aim of completing the decolonization of Africa. Formally committing itself to respecting borders as existing upon independence, at its second summit meeting, in Cairo, the OAU contradicted the Pan-African agenda of some of its founders, notably Nkrumah, but African leaders had three particular reasons for agreeing to adopt it. The first was to thwart the continuing attempts by colonial powers to impede or reverse decolonization, by-among other things-breaking up African territories to create enclaves that contained the most desirable resources (such as copper, gold and uranium) that could be run by their proxies. An example was Belgian backing for Katangese separatists in Congo. Colonial rulers had long practised divide and rule among their conquered peoples: post-colonial rulers feared this happening in a new guise. The second rationale was to find a workable basis for minimizing territorial disputes among African countries. Two border wars had already occurred-Algeria-Morocco and Ethiopia-Somalia-in the short time since the OAU's first summit. Third and most important, however much the leaders of newly independent African territories sought to legitimize their rule using romantic nationalist ideas, they also pragmatically set out to build their states on the Hobbesean model, which was the most readily accessible means of obtaining aid and security cooperation from Paris, London, Washington DC or Moscow.

By demanding respect for existing borders while simultaneously reaffirming member states' strict respect for the sovereignty and territorial integrity of each State, the OAU also ruled out support for separatism. The Pan-African programme of action was thus limited to providing support to liberation movements fighting racist and colonial rule, especially in southern Africa, and excluded groups such as the Eritreans and southern Sudanese from that solidarity. 
By limiting the right to self-determination in the colonial context to overseas colonies, the salt-water thesis made the right to self-determination appealing not only to those who derived an entitlement from it but also to those who wished to emphasize what it did not entitle to. Indeed, the formulation of the right of selfdetermination at the UN General Assembly in the 1960s at a time when the European colonies were either free from the imperial yoke or in the process of becoming so served less as an iteration of the right to decolonization (though that remained important in southern Africa in particular) and more as a means of denying the right to those who failed to fit the paradigm of a decolonizing territory, the colony being defined by overseas rule.

For instance, in supporting the articulation of self-determination as limited to the context of salt-water colonialism and its implementation in accordance with uti possidetis, Emperor Haile Selassie I of Ethiopia pursued not only general principles for Africa, but also specific territorial claims for Ethiopia, concerning Eritrea and the boundary with Somalia. The reason is that, during the late 19th century scramble for Africa, Ethiopia had been simultaneously the target of European imperial designs, and a junior participant in the great carve up. Haile Selassie's predecessor, Emperor Menelik II, had preserved his kingdom's independence in the 1880s and 1890s through force and guile. His army had fought the Italians and had won a famous victory at the Battle of Adwa in 1896. However, realizing that he could not drive the European colonizer out entirely, he had accepted the reality of Eritrea within its current boundaries. Meanwhile, the Emperor had also actively staked his own territorial claims, to the east, west and south of the Abyssinian heartland. The territory he ruled over was an empire that contained settlers, subjugated peoples and slaves. Following his successful prevention of the annexation of the empire and its expansion to new places, Ethiopians of Abyssinian highlands remember Menelik as the ruler who preserved their country's ancient sovereignty. By contrast, those in the country's peripheries recall him as a conqueror, who overran and seized their lands and who maintained them in subjugation through outposts of highland riflemen (neftegna). For the southern and eastern peoples, Ethiopia was 'invented' in that era, no less than other conquest states (Hassen, 1990; Holcombe \& Ibssa, 1990).

A generation later, when Ethiopia faced Italian Fascist invasion as Benito Mussolini's armies sought to conquer an African empire, the new Emperor became an icon of resistance. Haile Selassie's appeal to the League of Nations in June 1936 has rightly become a foundational text on collective security and the rights of small and poor states to be supported in their struggle to withstand aggression. He faced down the jeers of the Fascist journalists in the public gallery and gave his memorable speech:

I assert that the problem submitted to the Assembly today is ... not merely a question of the settlement of Italian aggression. It is collective security: it is the very existence of the League of Nations. It is the confidence that each State is to place in international treaties. It is the value of promises made to small States that their integrity and their independence shall be respected and ensured (Haile Selassie, 1936).

British Imperial troops and Ethiopian partisans restored the Emperor to his throne in 1941. In the annals of African history, Italy's rule over Ethiopia is not classified as colonization but rather as a temporary occupation, much as other axis powers briefly but terribly overran territories in Europe and Asia.

Back in power, Haile Selassie set about consolidating his own empire while advocating the dismantling of the European ones, always with an eye to the significance of multilateral institutions, politics and norms. Ethiopia signed the Declaration of the United Nations on January 1, 1942, and participated in the foundational UN Conference in San Francisco. The emperor instructed his diplomats to promote every multilateral norm and mechanism that was available. To give just one example, Ethiopia was one of 17 states to sign the Genocide Convention on the day it was presented to the UN-December 11, 1948-and was the first to ratify it, on July 1, 1949. Haile Selassie also supported African liberation movements against European colonial rule and put his own diplomats at the service of both African liberation movements and the OAU itself, Ethiopia, for instance, produced the first draft of the OAU 
Charter. His speeches in international fora were powerful pleas for racial equality and the emancipation of the colonized (Haile Selassie, 1963).

However, the majority of his imperial subjects had a different perspective: their support for his rhetoric was modulated by their own experience of subjugation. In a notable essay, the student activist Wallelign Mekonnen wrote:

Ask anybody what Ethiopian culture is? Ask anybody what Ethiopian language is? Ask anybody what Ethiopian music is? Ask about what Ethiopian religion is? Ask about what the national dress is? It is either Amhara or Amhara-Tigre!! To be a 'genuine' Ethiopian one has to listen to Amharic music, to accept the Amhara-Tigre religion, Orthodox Christianity, to wear the Amhara-Tigre shamma in international conferences. In some cases, to be an 'Ethiopian' you will even have to change your name. In short, to be an Ethiopian, you will have to wear an Amhara mask (to use Fanon's expression). (quoted in Balsvik, 1985, p. 277)

The imperial elite considered most Ethiopians to be second-class subjects. Some were pejoratively described as 'Galla' (Oromo). Others, known as 'Shankilla' and 'Baria' (Black peoples of the western and southern peripheries), were traded as possessions and treated as slaves (Baxter, 1983; Donham \& James, 1986). Most farmers were compelled to give a third, or even half, of their crops to feudal landlords, especially in areas outside the historic heartland in which armed settlers imposed themselves. The level of expropriation, colonial-style governance and enslavement was most extreme in the frontier areas of the empire, to the south, east and west (Markakis, 1987).

Haile Selassie was determined not to yield any of the territories that had been acquired by Menelik and sought to add more. He faced three different kinds of territorial challenges (Spencer, 1984, pp. 271-287). One was the demand of Eritrean nationalists for a state based on the colonial boundaries: they called it nationalism; he called it secessionism. Eritrea had been federated under the Ethiopian crown in 1952, through a contentious decision of the United Nations, and the Emperor abrogated that federation 10 years later. The UN never challenged him, but a growing number of Eritreans did. A second issue facing Ethiopia was straightforward boundary disputes, especially along the un-delineated borders with Kenya-on which Haile Selassie cleverly procrastinated until the British left. A third was a series of disputes during the 1950s with Italy and Britain over the status of his eastern territories, an area commonly known as the Ogaden after the principal Somali clan that lives there.3 Haile Selassie saw these disputes through the lens of the 1930s, as European conspiracies to weaken and defraud Ethiopia, not recognizing any legitimate claims the inhabitants might have had. He secured British withdrawal from the contested areas of Somaliland-the Haud-only in 1956 after arduous negotiations. The actors concerned had different perspectives on these negotiations. Somali nationalists saw them as the lost opportunity for uniting Somali peoples in one independent territory. The British were influenced by the agenda of reunifying Somalia but conducted the negotiations principally as a boundary issue. Haile Selassie refused to recognize any pan-Somali identity and treated the matter solely as a boundary dispute. And indeed there was a major unresolved issue: the major part of the Ethiopia-Somalia border has never been demarcated and is a provisional administrative line inherited from colonial days. In due course, the issue of Somali irredentism emerged with the Somali independence movement, which sought to separate the Somali-inhabited areas that had been incorporated into Ethiopia in Menelik's time and unite them in one Somali Republic.

The Emperor solved all three issues in one fell swoop with the adoption of the principle of respect of borders existing on achievement of independence and by deliberately conflating the three distinct issues. At the OAU's second summit, Haile Selassie incorrectly portrayed the Somali claims on Ethiopia as exclusively a boundary dispute (comparing it to the Morocco-Algeria border conflict). He also linked recognition of existing boundaries to non-interference in internal affairs. He and the other African leaders in Cairo were silent on the self-determination of groups within states and in effect subsumed this issue under the boundary question. The 
timing of the summit also suited the Ethiopian ruler, as he had recently abrogated the 1952 federal arrangement for Eritrea, absorbing the former Italian colonial territory into his own empire, without protest at the UN, which was ostensibly the guarantor of Eritrea's federal status. By adopting the principle of respect for borders existing on the achievement of national independence, the OAU seemed to condone the abrogation: even when a state violated internal or internationally agreed governance arrangements, its boundaries would remain those as at independence.

The Somali delegation to the inaugural OAU summit had threatened to vote against the OAU Charter, as the principle of respect for territorial integrity threatened to block the route to the unification of the territories of the Somali speaking people in a single nation-state. The Somali delegates were persuaded not to spoil the party, but their fears proved well-founded, when they were outmanoeuvred at the Cairo summit the following year-only Somalia and Morocco (which also had an irredentist claim) voted against the resolution. The five-pointed Somali flag remains a standing rebuke to the principle of respecting inherited colonial borders. By refusing to consider any diplomatic means of addressing the Somali claims, Ethiopia sowed the seeds of the 1977 Ogaden war, when the Somali government tried to take the Somali-inhabited territories of Ethiopia by force.

The Ethiopian political left was actively involved in debating, and often resisting, the Emperor's schemes. Of particular relevance to this collection, the student movement debated-and failed to resolve-two inter-related questions, namely, 'what does it mean to be an Ethiopian?' (Balsvik, 1985) and who was entitled to statehood and in what form? Thus, immediately prior to the 1974 revolution that deposed the emperor and instated a military committee that embraced communist principles, and during the early years of that upheaval, the Ethiopian left hotly debated the distinction between those territories and peoples unconditionally entitled to exercise self-determination including secession on the basis of their status as a colony, and those entitled to other formulations of group rights on the basis of being nations, nationalities or peoples. The Marxist-Leninist formulation guided all these discussions, as it did the entire praxis of the country's progressive movement at the time. As a result, Stalin's theory of nations became relevant to our topic of nationalism and self-determination.

At the global level, however, Ethiopia's push for, and the OAU's adoption of, the principle of respect for borders existing on achievement of independence was entrenched in international law. In the Burkina Faso/Mali case, the International Court of Justice equated the parties' invocation of the 'principle of the intangibility of frontiers inherited from colonization', and the expression used in the Cairo Declaration, with the principle of uti possidetis. According to the Court,

the numerous solemn affirmations of the intangibility of the frontiers existing at the time of the independence of African States, whether made by senior African statesmen or by organs of the Organization of African Unity itself, are evidently declaratory rather than constitutive: they recognize and confirm an existing principle, and do not seek to consecrate a new principle or the extension to Africa of a rule previously applied only in another continent. (ICJ, 1986, para. 24).

While this finding has been criticized (Dirdeiry, 2015) on the basis of the differences set out above between the principles of uti possidetis and of respect for boundaries at the time of independence, the result of this judgement is that the principle that the OAU was most interested in is now often considered as part of uti possidetis. The principle has not become more coherent for it, given the different functions of the original uti possidetis rule and the OAU principle. Still, whereas Boutros Boutros-Ghali had once lamented that 'the adoption of the principle of uti possidetis [in the OAU Charter] would have been an important step toward expanding the role of international law in Africa' (Boutros-Ghali, 1964, p. 30), the OAU in fact managed to expand, intentionally or not, the understanding of uti possidetis in international law to incorporate a rule that it was promoting. The flipside for African states is that the Spanish American uti possidetis rule is also deemed applicable to them, even in the absence of their support for it. According to the ICJ, this broader understanding of uti possidetis covers 'the phenomenon of the obtaining of independence, wherever it occurs' (ICJ, 1986, para. 20). 


\subsection{Secession}

The Horn of Africa's second contribution to global norm development is providing state practice to demonstrate that commitment to territorial integrity, respect for borders existing at independence, or uti possidetis in its broad sense, does not stand in the way of recognizing states created through secession with the consent of the rump state. Between the 1960s and the 1990s there was little practice to that effect4: the global territorial dispensation was remarkably stable. Only in 1991 did the creation of states begin anew. It was most conspicuous with the disintegration of Yugoslavia and the Soviet Union, and the independence of Timor Leste, but the first case was in the Horn. In an intriguing anecdote, in May 1991, when U Assistant Secretary of State Herman Cohen called his superior, Secretary of State James Baker, to inform him that he had just presided over an agreement to end the war in Ethiopia and Eritrea that entailed the Eritreans having a vote on independence, Baker is reported to have responded '[a]nd what the [expletive] am I supposed to tell the Croats?'5 Two decades later, South Sudan's independence, recognized by Sudan and subsequently all other African states, provided a second instance in which the Horn of Africa provided state practice to evince this nuance of the rule.

\subsection{The responsibility to protect}

Finally, and least directly, the Horn of Africa has contributed to the development of a norm that stands in a complex relationship with the right to self-determination: the doctrine of the Responsibility to Protect (R2P).

In political practice, the Horn has been the site of several important innovations related to R2P. One was the US intervention in Somalia in 1992-1993, 'Operation Restore Hope'. This was a military intervention under Chapter VII of the UN Charter, aimed at providing a secure environment for the delivery of humanitarian relief in a collapsed state. Although R2P advocates later tried to disavow a connection between military humanitarian interventions of this kind and R2P, this was chiefly because the 'Black Hawk down' debacle in Mogadishu in 1993 rendered discussion of such missions politically toxic, especially in Washington DC. The story of the failed intervention is too complex to recount here, but important themes including obscuring politics under a humanitarian banner and overriding humanitarian law in the conduct of the operations in the name of the ostensibly higher authority provided by the UN Security Council (De Waal, 1997) have recurred in subsequent interventions from Kosovo to Libya. Twenty years later, the war and massacres in Darfur were the occasion of a concerted international campaign to label the events as 'genocide' and leverage US military intervention to halt the killings, protect the civilian population and (implicitly among many of the Save Darfur advocates) change the regime in Khartoum. As the first high-profile crisis of mass atrocity after the report of the International Commission on Intervention and State Sovereignty (ICISS) and its formulation of the principle of R2P, this was seen as a test case of R2P.

Even more important for the purpose of this collection than these precedent-setting cases is the intellectual genealogy of the doctrine of R2P, which has its roots in the region. The forerunner to R2P was the theory of 'sovereignty as responsibility', which was developed by the Sudanese/South Sudanese scholar and diplomat Francis Deng, in his capacity as UN special rapporteur on internally displaced persons (Rothchild \& Deng, 1996). While Deng made his analysis and recommendations universal, it is clear that he drew heavily on his experience of his home country (Deng, 1994). According to his theory, sovereignty comes not merely with rights but also with responsibilities vis-àvis people subject to the sovereign. Consequently, and this leads to one of the 'pillars' of R2P as it was subsequently formulated, if a state fails to fulfil its responsibility to protect its own citizens, it loses its sovereign right to be free from foreign intervention.

Deng's theory can be seen as supporting the theory of remedial secession in that if a state commits one of the R2P crimes (genocide, crimes against humanity, war crimes and ethnic cleansing) against its own people, it no longer has a sovereign right to be free from foreign intervention, and other states are thus possibly free to support a secessionist movement. In Deng's theory, 
a state which discharges its responsibilities towards its citizens, individuals and groups, through constructive management of diversity, democratic participation, equitable sharing of wealth and development opportunity, and respect for fundamental human rights and civil liberties, is not likely to be a candidate for the fragmenting exercise of self-determination. (Deng, 1994, p. 3)

But the other side of the coin is that 'a state which fails grossly to meet these basic objectives of good governance can expect the aggrieved groups to demand self-determination in its separatist version, leading to secession.' (Deng, 1994, p. 3) The difference with the theory of remedial secession is that in Deng's formulation it is a matter of fact that aggrieved groups will demand self-determination in its separatist version, leading to secession; in the theory of remedial secession, these groups have the right to secede on account of the grievances.

In the subsequent reformulation of sovereignty of responsibility as R2P, notably by the ICISS, the emphasis shifted from a state's responsibility towards its own citizens, including respect for elements of internal self-determination, to the criteria for international military intervention in case that state committed the so-called atrocity crimes (genocide, crimes against humanity and war crimes) and ethnic cleansing. While the term R2P thus reflected Deng's notion of responsibility, it ended up in the ICISS report as a reconceptualised version of humanitarian intervention.

When we turn to examining the political work that self-determination and R2P have been made to do, we can see that they are useful for contrasting political agendas (Jansen, 2017). While potentially supporting selfdetermination as a right to secession, R2P has served as the antithesis of self-determination as a people's right to determine their own political future. The emancipatory political impulse behind self-determination is that it should enable a people to gain equitable political agency in a world of states. As its inclusion, as the very first human right in the general international human rights treaties confirms, self-determination can be envisaged as the master switch for realizing other human rights. The principle of R2P is concerned only with the right to life. Self-determination deals with political communities, which have organized themselves to claim the right; R2P deals with 'populations', conceived of as either inert agglomerations of individuals or groups protected by the Genocide Convention, namely, national, ethnic, racial or religious groups. Self-determination assumes agency of active people who are claiming political rights; R2P depends on the 'international community' as agent for protecting the bare life of passive populations at risk (cf. Agamben, 1998). Self-determination is available to be invoked to challenge historic structures of dispossession and repression; R2P is invoked in response to mass atrocity crimes as discrete events. Self-determination is a norm to protect political organization; R2P is organized around the idea of 'crimes', which are seen to flow from the criminal intent of a few individuals, and thus ignores the politics of a particular situation, making it easier for outsiders to see it as their place to intervene militarily.

In the current discourse of global politics-more rhetorical than legal-R2P may be seen as displacing the right of self-determination as the most fundamental international mechanism for remedying gross collective injustice and, in doing so, depoliticizing the resistance to oppression. In the current era, lobby groups and many western policymakers grant the 'master switch' role to R2P, at least, when Africa is concerned. However, such a shift has yet to play out decisively, and the falling apart of Libya after intervention under the banner of R2P has dealt the concept a severe blow.

\section{5 | NATIONALISM AND SELF-DETERMINATION IN THE HORN OF AFRICA TODAY}

The articles in this collection bear out how nationalism and self-determination have had different meanings in the political cultures across the different countries of the Horn of Africa and across time. 


\section{1 | Varieties of nationalism}

Questions of national identity are unresolved in each country-and in each country in a different manner. Publics and elites have debated the question 'who are we?' for a century or longer. It is debated in different idioms and with different reference points in different countries.

As described by Peter Chonka and Sally Healy for Somalia, despite the ethno-linguistic homogeneity of the dominant part of the Somali ethno-nation, which has supported a particularly enduring primordialist narrative to Somali identity, the Somali nation has always been a contested construction. Somali anti-colonialists united in support of a 'Greater Somalia' as a project of political unification. This died at some point between military defeat by Ethiopia in 1978 and the collapse of the central government in 1991, since when the peninsula has been characterized by much more fragmented political-territorial realities. Nonetheless, ideas of an ethnolinguistic, cultural and religious 'nation' still persist, finding expression in the Somali language, media and in local political discourse, notably by Islamists including Al Shabaab. Meanwhile, in the different polities that have arisen across the 'Somali' nation, there are diverse and ambiguous nationalisms, represented in the naming of the (separatist) Republic of Somaliland and the wonderfully inclusive-or paradoxical-title of the Ethiopian Somali National Regional State. Chonka and Healy conclude that Somali identities can be multiple, relational and potentially contradictory and can burst the boundaries of existing political forms, notably those established by the Federal Government of Somalia, leaving questions of national self-determination very much unresolved and alive.

The Sudanese, by contrast, were never able to construct a primordialist nationalist narrative, as explained in Alex de Waal's contribution. Independence from British and Egyptian imperial powers in the 1950s-described at the time as an exercise in self-determination-meant different things to different Sudanese constituencies. The Sudanese case has many interesting elements, among them are the Islamists' dilemmas in grappling with what nationalism and self-determination should mean to Muslims-a problem that has been managed, but not resolved, by presenting different stories to different audiences. Somali Islamists have faced the same problem and addressed it in the same manner.

The state of South Sudan has come about in the name of self-determination through political challenge and armed conflict. Protracted struggle in what is represented as a just cause has been an intrinsic element in constituting a sense of common national identity. South Sudanese arguments for a distinct identity in comparison and contrast to the (northern) Sudanese draw on ethno-racial primordialism, narratives of injustice and narratives of armed struggle, which in turn script different but overlapping local concepts of the nation, its citizens and its boundaries.

Mulugeta Gebrehiwot Berhe and Fiseha Haftetsion Gebresilassie explore the political narratives and processes of nationalism and self-determination in Ethiopia, a country that has never been compelled to achieve decolonization from a European power. Strikingly, it is in Ethiopia-the sole African country that boasts political continuity under its own rulers throughout modern times-that the concept of 'nation' is itself radically ambiguous, so that Ethiopian scholars and jurists can describe the country as 'a nation of nations'. Berhe and Gebresilassie argue that the 1995 federal constitution, while granting extensive rights of self-rule to Ethiopia's constituent nations, has in political practice been contradicted by the vanguardist centralism of the Ethiopian People's Revolutionary Democratic Front (EPRDF). This has led to a situation in which the project of nationalism has degenerated from socio-cultural emancipation into a charter for rent seeking by local elites, in a form of regressive administrative nationalism.

Eritrea and Djibouti do not receive extended treatment in this collection of papers. However, each manifests a particular configuration of the issues.

Eritrean nationalism is rooted in the peculiar colonial experience of Eritrea, the recurrent debates among Eritrean political elites about the direction that their country should take and the protracted armed struggle for independence. Italy's occupation of the territory of Eritrea posed a legally straightforward case for decolonization, but this 
was complicated by the United Nations' decision to federate Eritrea 'under' the Ethiopian crown in 1952. This was a politically unstable and unsustainable solution that led within 10 years to Ethiopia's abrogation of the federal arrangement and an armed insurrection demanding independence. While the legal case for Eritrea's right to selfdetermination as an exercise in decolonization was always strong, Eritreans' ability to exercise that right depended entirely on political and military facts on the ground. The Eritrean People's Liberation Front (EPLF) articulated a vision that combined independence and revolutionary social transformation and developed the political-military capacity to prevail. The EPLF's battlefield victory made it possible for self-determination in the sense of national independence to be successfully attained. Militarized liberation war was followed by authoritarian politics. In his paper presented at the seminar from which this collection derives, Paulos Tesfagiorgis described the EPLF's ideology as 'vanguard nationalism', going on to recount how the leadership abandoned self-determination in the sense of democratic participation (Tesfagiorgis, 2020).

Djibouti was the last country in the Horn to receive de jure independence from a European colonial power, posing several problems for the region (Franck \& Hoffman, 1976). During the era of decolonization, both Ethiopia and Somalia laid claims to the territory, while France was determined to retain, at the very minimum, the rights to its strategically important military base. The French policy consisted of holding referenda which it was confident would show majority support for continued association with France while prevaricating until there was a propitious moment to grant independence on terms favourable to French interests. Two referenda (in 1958 and 1967) yielded results in which the ethnic Somalis voted first for unification with Somalia and later for independence, while the ethnic Afars voted the other way, along with French nationals. Eligibility for voting was tightly controlled and controversial, given both the mobile nature of the population and the cross-border nature of the communities, and the stakes of the outcome. The declaration of the pro-France result of the 1967 referendum led to riots and to Somalia and Ethiopia each mobilizing troops along their respective borders with an implicit threat of invasion. The crisis was defused when African governments discreetly agreed with France that the status quo was preferable to an inter-state war (Marks, 1974, p. 102). Only in 1977, after the revolutionary government in Ethiopia abandoned its claim to the territory, did France belatedly accede to the international norm and grant independence.

However, the often arbitrary French management of the electoral roll has had as its legacy an ongoing contest over the ideology and practice of citizenship (Bezabeh, 2011). France's divide-and-rule tactics also deepened the ethnic divide, contributing to civil war in the 1990s.

\section{2 | Varieties of self-determination}

The varieties of meanings and consequences that self-determination can have in international law have all surfaced in the Horn of Africa. Self-determination has been invoked as a ground for independence from the colonizer; for unification across existing boundaries; for autonomy of a people within a state; for secession on grounds of political oppression and human rights violations; and more. The grounds are often invoked in combination, with emphases changing over time.

Theoretically, the different approaches to self-determination can be seen as going hand in hand. For instance, creating a new state to replace an imperial state or removing an occupying power can enhance the opportunities for people to participate in political processes and securing all other citizens' rights. However, the promotion of one type of self-determination (for instance, a right to secession) can also be in tension with another type of selfdetermination (for instance, the right to participate in the shaping of a state's political affairs). In the Sudanese case, self-determination served as a formula for resolving a conflict and not a formula for building a long-lasting political community: South Sudanese separatism was a rival project to democratization across the whole of Sudan, and democratization was ultimately the casualty. Other tensions exist, too. The means undertaken to realize external self-determination, notably armed struggle, can lead to militaristic and undemocratic post-liberation governments 
assuming power. Somaliland on the one hand and Eritrea and South Sudan on the other demonstrate the tension between building a nation with a form of democratic governance and establishing an internationally recognized state; Somaliland has progressed remarkably in the former but not the latter, while Eritrea and South Sudan have had the opposite experience.

This tension is also the result of competing rationales for self-determination. The fact that self-determination has been recognized as a human right suggests a deontological rationale: it must be respected for its own sake. In practice, however, self-determination has often been adopted for instrumental reasons, as a means to pursue something else, in particular, to resolve a civil war.

Once self-determination has been canvassed as a possible mechanism for resolving a political problem, it rarely goes away: the term has a remarkable capacity of defining the ostensible solution as soon as it is raised. Part of the story of South Sudan is an instrumental deployment of self-determination as a proposed means of resolving a longrunning civil war, sliding inexorably into ethnic partition, which failed to resolve the problems that had led to war in either (northern) Sudan or South Sudan.

In a similar vein, the communist theory of nations was formulated as a reaction to a specific problem: how to enlist the disparate historically subjugated peoples of the Russian empire in a common revolutionary project, overcoming the 'narrow nationalism' of these peoples who were interested more in independence for their territories than revolution across the Russian Empire, while keeping 'Greater Russian chauvinism' at bay. The theory was articulated in the USSR Constitution as a mechanism of managing political conflicts and keeping the Union together. However, in an instrumental approach, self-determination's meaning and role become malleable to the perceived best interests of the political project and those in charge of that political project. In the USSR, self-determination was subservient to the interests of Stalin, the Soviet state and socialism (Mälksoo, 2017; Martin, 2001). The contradictions between the Marxist-Leninist theory and its application could thus be justified politically by the anticipated outcome: socialist transformation in which national identities were submerged by class solidarity. Legally, Soviet lawyers denied the contradictions by arguing that when a people had exercised its free choice to remain in a multinational state, which the peoples of the USSR were presumed to have done, the right to self-determination in the sense of a right to independence expired unless the conditions of the union were violated (Hazard, 1966, p. 868). Over time, the formula in the Soviet Constitution became a mechanism for promoting linguistic and cultural identity politics and for the allocation and use of administrative prebends by members of those national groups.

The USSR's experience with self-determination remains relevant for the Horn of Africa because the Horn is, perhaps uniquely, a place in which the Marxist-Leninist-Stalinist theory of nations and self-determination lives on in the contemporary era. The 1995 Ethiopian constitution awards the right of self-determination up to and including secession, to the country's constituent nations. But as Berhe and Gebresilassie demonstrate, in Ethiopia, too, the 'nations' become instruments for the central party's political objectives. Their notion of administrative nationalism parallels the concept of administrative tribalism, which refers to the way in which political powers (colonial and postcolonial) refashioned and sometimes invented customary authority for the purposes of indirect rule or native administration, for purposes of pacification, local government and counterinsurgency, as cheaply as possible (Mamdani, 1996; Ranger, 1983). As with its Soviet forebear, the Ethiopian formula for nationalism and selfdetermination within an empire-state transformed by revolution first solved an immediate political problem (how to secure broad-based representation in a fragile transition) and then in time posed new, different political problems. Indeed, the EPRDF's de facto management of federal politics bore many of the hallmarks of 'vanguard nationalism' (Tesfagiorgis, 2020).

The divergent discourses of nationalism and self-determination abut one another in intriguing ways. Ethiopia's federal constitution has awarded the status of 'nations' to groups that straddle its boundaries. Chonka and Healy observe how Somali speakers within Ethiopia are still wistfully known as 'Western Somalis' by pan-Somali nationalists, while their federal state is entitled the 'Ethiopian Somali National Regional State', with the 'national' in its Somali name, deegaan, also having the historic reference of a fluid clan-territorial 'homeland'. On Ethiopia's western border, 
Gambela State was set up to provide a homeland for the indigenous Nilotic peoples of Gambela, who comprise Nuer and Anuak-groups that have been in political competition with one another and which are enmeshed in South Sudanese politics and conflict.

\section{3 | Protecting self-determination}

A prevalent way to try to guarantee the right to self-determination is to incorporate it into texts: declarations of principles, peace agreements and constitutions. Those texts are created in particular political contexts, often with the intent of addressing specific political challenges. The Ethiopian transitional charter of 1991 (which recognized the independence of Eritrea) and the Federal Constitution of 1995 were created as political texts. So were the texts of Sudanese agreements in which the notion of self-determination evolved, from the southern delegations' joint position at Abuja (1993), the InterGovernmental Authority on Development (IGAD) Declaration of Principles (DoP) (1994), the Machakos Protocol (2002) and the Comprehensive Peace Agreement (2005). However, the moment selfdetermination is enshrined in text, the debate over its meaning in the abstract shifts to a debate over its meaning in the text. And the moment political texts are created with a view to render agreements made binding, the key question becomes who controls the text's interpretation.

Self-determination is a potentially revolutionary concept-in some of its understandings, it can create new states. One feature in all experiences surveyed in the Horn of Africa is that those who use the concept believe they can control the interpretation and thus the revolutionary outcomes that it entails. This appears to be true only in the short term, but when the self-determination card has been played, it does not quietly return to the deck. Instead, it is taken into the hands of others to be played in different ways. The parties drafting and signing peace agreements and constitutional texts treated them as political documents that they would be able to control, rather than as legal texts that might be adjudicated by an external actor. As de Waal's discussions of the IGAD DoP illustrate, there was therefore limited attention for precise or detailed drafting.

In some instances, parties have indeed kept the control over the interpretation of the text, but at a high cost. The idea of and attempt at control is a risk to self-determination in its democratic sense. If parties believe they can control the implementation of the text, how can the political space that self-determination is supposed to create be protected against usurpation by the most politically powerful actors? Self-determination becomes an instrument of those powerful actors, rather than a constraint on the exercise of political power. The Eritrean president maintains total control over all aspects of Eritrean political and social life, ruling without a constitution or a consultative mechanism, despite the recent opening up to Ethiopia. Until 2018, the EPRDF maintained tight control over politics and administration in Ethiopia, but at the cost of a degenerating public political sphere. As noted by Dawit Mesfin in the seminar at which these papers were discussed, 'we seem to operate in this part of the world with invisible powers (and not law and constitutions) dictating the outcomes.'

The Sudan/South Sudan experience bears out, however, that the drafters and initial signatory parties losing the control over the meaning of self-determination in the text need not secure self-determination in its democratic sense either. In the case of Sudan/South Sudan, international championship of self-determination and international reading of what it meant have been crucial. The absence of self-determination (whether in the form of independence or autonomy) was one factor among many in the outbreak and intractability of the Sudanese civil war and at no point was it the most significant part-until it was named as such, when it became the circuit breaker for every other piece of political wiring. Having been legitimized by an international document-the IGAD DoP, which ironically did so with mixed motives and the expectation that the outcome would be a united Sudan-self-determination became the nonnegotiable word in the Sudanese peace talks. But when the dominant interpretation of self-determination became secession, self-determination in its democratic aspect again lost out. For self-determination to fulfil its democratic and emancipatory role it requires a protected political space in which a collectivity of people can determine their identity. 


\section{6 | CONCLUSION}

What work is ultimately done by the concept of self-determination? On its own, self-determination lacks content. Specified in relation to a political circumstance, it takes on meaning-a meaning as changeable and contestable as those political circumstances themselves.

The Horn of Africa emerges from this collection as a kind of theme park for self-determination, where the ticket holder can choose among a range of different rollercoasters-none of which advertise their ultimate destinations or safety certificates. But one thing that does become clear from all the case studies is that self-determination as a right to independence is more concrete and therefore more easily implemented than self-determination in its democratic sense. An intuitive response may be to argue that self-determination in the latter sense should be made more concrete and more detailed, and to reduce self-determination's indeterminacy. However, we argue that the determinacy of self-determination in its secessionist sense is more of the problem than the indeterminacy of self-determination in its democratic sense. Self-determination is about identity, and identities cannot be imposed or fixed. Nationalism is also indeterminate: nations are constituted by historical forces and consequently are changeable. Our principal conclusion is to embrace self-determination's indeterminacy and protect it. Indeterminate norms can be stronger than concrete ones. Once people insist on rights as defined by a particular rubric, it spells an end to negotiation-with one's own constituency and with others.

\section{ACKNOWLEDGEMENTS}

The authors thank the authors of the contributions to this Special Collection (Peter Chonka, Mulugeta Gebrehiwot Berhe, Fiseha Haftetsion Gebresilassie and Sally Healy) for their rich articles and Paulos Tesfagiorgis for his insightful working paper 'Vanguardist Nationalism in Eritrea'. The authors also thank Megan Donaldson, Mulugeta Gebrehiwot Berhe and Sally Healy for their insightful comments and Orfeas Chasapis-Tassinis for copy-editing and comments on this introduction. The World Peace Foundation, the Economic and Social Research Council (grant ES/L010976/1), the Leverhulme Trust (PLP-2014-067) and Isaac Newton Trust (RG79578) supported Nouwen's research and an authors' workshop developing this Special Collection.

\section{ENDNOTES}

${ }^{1}$ See common Article 1 of International Covenant on Civil and Political Rights, 16 December 1966, 999 United Nations Treaty Series 171 and International Covenant on Economic, Social and Cultural Rights, 16 December 1966, 993 United Nations Treaty Series 3.

${ }^{2}$ Key moments in the normative development of this right were General Assembly resolutions 1514 (XV), $1541(X V)$ and 2625(XXV).

3 The Emperor also argued that the French-occupied territory of Djibouti should be part of Ethiopia, but never assertively pursued his claim.

${ }^{4}$ One glaring example seems to be the 1973 secession of Eastern Pakistan, but Bangladesh was internationally recognized only after Pakistan consented.

${ }^{5}$ Herman Cohen, personal communication with Alex de Waal, June 1991. This occurred at a crucial juncture in the breakup of Yugoslavia, with the United States opposed to European countries in holding the line in support of a unified Yugoslav Federal Republic.

\section{REFERENCES}

Agamben, G. (1998). Homo Sacer: Sovereign power and bare life. Stanford: Stanford University Press.

Anderson, B. (1999). Indonesian nationalism today and in the future. New Left Review, 235, 3-17.

Balsvik, R. R. (1985). Haile Selassie's students: The intellectual and social background to revolution, 1952-1977. East Lansing, MI.

Baxter, P. (1983). The problem of the Oromo or the problem for the Oromo? In I. Lewis (Ed.), Nationalism and selfdetermination in the horn of Africa (pp. 129-149). London: Ithaca Press. 
Bezabeh, S. (2011). Citizenship and the logic of sovereignty in Djibouti. African Affairs, 110/441, 587-606. https://doi.org/ 10.1093/afraf/adr045

Biney, A. (2011). The social and political thought of Kwame Nkrumah. New York: Palgrave Macmillan. https://doi.org/10. $1057 / 9780230118645$

Boutros-Ghali, B. (1964). The Addis Ababa Charter. International Conciliation, 35(3), 29-62.

Brubaker, R. (1994). Nationhood and the national question in the Soviet Union and post-Soviet Eurasia: An institutionalist account. Theory and Society, 23(1), 47-78. https://doi.org/10.1007/BF00993673

Clapham, C. (2016). The Horn of Africa: State formation and decay. London: Hurst.

Crawford, J. (2008). The creation of states in international law (2nd ed.). Oxford: Oxford University Press.

De Waal, A. (1997). U.S. war crimes in Somalia. New Left Review, 230(July/August), 131-144.

Deng, F. M. (1994). Protecting the dispossessed: A challenge for the international community. Washington DC: Brookings Institution.

Dirdeiry, M. A. (2015). Boundaries and secession in Africa and international law: Challenging uti possidetis. Cambridge: Cambridge University Press. https://doi.org/10.1017/CBO9781316339008

Donham, D., \& James, W. (1986). The southern marches of Imperial Ethiopia: Essays in history and social anthropology. Cambridge: Cambridge University Press.

Fearon, J., \& Laitin, D. (2000). Violence and the social construction of ethnic identity. International Organization, 54(4), 845-877. https://doi.org/10.1162/002081800551398

Franck, T. M., \& Hoffman, P. (1976). The right to self-determination in very small places. New York University Journal of International Law and Politics, 8(3), 331-386.

Gellner, E. (1983). Nations and nationalism. Ithaca, NY: Cornell University Press.

Gilroy, P. (1993). The black Atlantic: Modernity and double consciousness. Cambridge, MA: Harvard University Press.

Haile Selassie. (1936). Discours prononcé par Sa Majesté Haylé Sélassié ler, empereur d'Éthiopie, à l'Assemblée de la Société des Nations, à la session de Juin-Juillet 1936, 30 June 1936 League of Nations Archives.

Haile Selassie. (1963). Speech, UN general Assembly 18th session, 4 October 1963, UN Bibliographic Information System, available from https://documents-dds-ny.un.org/doc/UNDOC/GEN/NL6/303/10/PDF/NL630310.pdf?OpenElement

Hannum, H. (1998). The specter of secession: Responding to claims for ethnic self-determination. Foreign Affairs, 77(2), 13-18. https://doi.org/10.2307/20048785

Hassen, M. (1990). The Oromo of Ethiopia: A history, 1570-1860. Cambridge: Cambridge University Press.

Hazard, J. N. (1966). Soviet Yearbook of International Law 1962 and Soviet Yearbook of International Law 1963. American Journal of International Law, 60, 868-870.

Healy, S. (1983). The changing idiom of self-determination in the Horn of Africa. In I. Lewis (Ed.), Nationalism and selfdetermination in the Horn of Africa (pp. 93-110). London: Ithaca Press.

Higgins, R. (1994). Problems and process: International law and how we use it. New York: Clarendon Press.

Holcombe, B., \& Ibssa, S. (1990). The invention of Ethiopia: The making of a dependent colonial state in Northeast Africa. Trenton, NJ: Red Sea Press.

International Court of Justice. (1975). Western Sahara Advisory Opinion, I.C.J. Rep. 116 (16 October) (Separate Opinion of Judge Dillard).

International Court of Justice. (1986). Frontier Dispute (Burkina Faso/Mali), I.C.J. Rep. 554 (22 December).

International Court of Justice. (1992). Land, Island and Maritime Frontier Dispute (El Salvador/Honduras: Nicaragua Intervening), I.C.J. Rep. 350 (11 September).

International Court of Justice. (2010). Accordance with International Law of the Unilateral Declaration of Independence in Respect of Kosovo, I.C.J. Rep. 403 (22 July).

International Court of Justice. (2013). Frontier Dispute (Burkina Faso/Niger), I.C.J. Rep 134 (16 April) (Separate Opinion Judge Yusuf).

International Court of Justice. (2019). Legal Consequences of the Separation of the Chagos Archipelago from Mauritius in 1965 (General List No. 169) (25 February).

Jansen, A. (2017). Anti-genocide activists and the responsibility to protect. London: Routledge. https://doi.org/10.4324/ 9781315535098

Koskenniemi, M. (1994). Self-determination today: Problems of legal theory and practice. International and Comparative Law Quarterly, 43, 241-269. https://doi.org/10.1093/iclqaj/43.2.241

Lewis, I. (Ed.) (1983). Nationalism and self-determination in the Horn of Africa. Exeter: Ithaca Press.

Mälksoo, L. (2017). The Soviet approach to the right of peoples to self-determination: Russia's farewell to Jus Publicum Europeaum. Journal of the History of International Law, 19, 200-218. https://doi.org/10.1163/15718050-19231035

Mamdani, M. (1996). Citizen and subject: Contemporary Africa and the legacy of late colonialism. Princeton, NJ: Princeton University Press.

Markakis, J. (1987). National and class conflict in the horn of Africa. Cambridge: Cambridge University Press. 
Marks, T. (1974). France's strategic toehold in Africa. African Affairs, 73(290), 95-104. https://doi.org/10.1093/ oxfordjournals.afraf.a096459

Martin, T. (2001). The affirmative action empire: Nations and nationalism in the Soviet Union, 1923-1939. Ithaca: Cornell University Press. https://doi.org/10.7591/9781501713323

OAU Charter. (1963). Charter of the Organization of African Unity.

Organization of African Unity. (1964). Border disputes among African states, AHG/res. 16(I), the Assembly of Heads of State and Government Meeting in its First Ordinary Session in Cairo, UAR, 17-21 July.

Ranger, T. (1983). The invention of tradition in colonial Africa. In E. Hobsbawm, \& T. Ranger (Eds.), The invention of tradition (pp. 211-262). Cambridge: Cambridge University Press.

Rothchild, D., \& Deng, F. (1996). Sovereignty as responsibility: Conflict management in Africa. Washington, DC: Brookings.

Spencer, J. H. (1984). Ethiopia at bay: A personal account of the Haile Sellassie years. Algonac, MI: Reference Publications.

Stalin, J. (1913). Marxism and the national question. First Published: Prosveshcheniye, Prosveshcheniye. Nos. 3-5, (MarchMay). https://www.marxists.org/reference/archive/stalin/works/1913/03.htm

Supreme Court of Canada. (1998). Reference re Secession of Quebec, 2. S.C.R 217.

Tesfagiorgis, P. (2020). Vanguardist nationalism in Eritrea. Somerville, MA: World Peace Foundation. Occasional Paper No. 22, May

United Nations. (1950). General assembly resolution 390(V), Eritrea: Report of the United Nations Commission for Eritrea; Report of the Interim Committee of the General Assembly on the Report of the United Nations Commission for Eritrea, a/RES/390(V) (2 December 1950).

United Nations. (1960). General Assembly resolution 1514(XV) Declaration on the granting of independence to colonial countries and peoples, A/RES/1514(XV) (14 December 1960).

United Nations. (1970). General Assembly resolution 2625(XXV), Declaration on Principles in International Law concerning Friendly Relations and Co-operation among States in accordance with the Charter of the United Nations, A/RES/2626/(XXV) (24 October 1970).

United Nations. (1976). General Assembly resolution 31/53, Question of Timor A/RES/31/53 (1 December 1976)

United Nations. (1977). General Assembly resolution 32/116, Question of Southern Rhodesia, A/RES/32/116 (17 December 1977).

United Nations. (1979). General Assembly resolution 34/37, Question of Western Sahara A/RES/34/37 (21 November 1979)

How to cite this article: de Waal A, Nouwen SMH. The necessary indeterminacy of self-determination: Politics, law and conflict in the Horn of Africa. Nations and Nationalism. 2020;1-20. https://doi.org/10.1111/ $\underline{\text { nana.12645 }}$ 